\title{
Taxonomic and scientific inaccuracies in a consultancy report on biodiversity: a cautionary note
}

\author{
Mohomed M. Bahir ${ }^{1}$ \& Dinesh E. Gabadage ${ }^{2}$ \\ 1,2 Taprobanica Nature Conservation Society, 146, Kendalanda, Homagama, Sri Lanka \\ Email: goodwillserve@gmail.com ${ }^{1}$
}

Date of online publication 26 June 2009 ISSN 0974-7907 (online) | 0974-7893 (print)

Editor: Indraneil Das

\section{Manuscript details:}

Ms \# 02123

Received 23 January 2009

Final received 09 May 2009

Finally accepted 04 June 2009

Citation: Bahir, M.M. \& D.E. Gabadage (2009). Taxonomic and scientific inaccuracies in a consultancy report on biodiversity: a cautionary note. Journal of Threatened Taxa 1(6): 317322

Copyright: (C) M.M. Bahir \& D.E. Gabadage 2009. Creative Commons Attribution 3.0 Unported License. JoTT allows unrestricted use of this article in any medium for nonprofit purposes, reproduction and distribution by providing adequate credit to the authors and the source of publication.

Author Details: Mohomed M. Bahir, the coordinator of the Taprobanica Nature Conservation Society is a conservation research biologist working on freshwater crab and reptile taxonomy. Also, he has been working on amphibian life histories. DINESH E. GABADAGE, the secretary of the Taprobanica Nature Conservation Society is a conservation field biologist working on Sri Lankan herpetofauna and promoting conservation awareness of the value of biodiversity among Sri Lankan community.

Author contributions: Both authors have equally contributed to this study and in writing the paper.

Acknowledgements: We thank an anonymous reviewer for improving the manuscript. We thank Prof. Colin P. Groves (Australian National University) for being a critical reviewer of this manuscript. We also thank anonymous reviewers for their comments and our colleagues for encouraging this work.
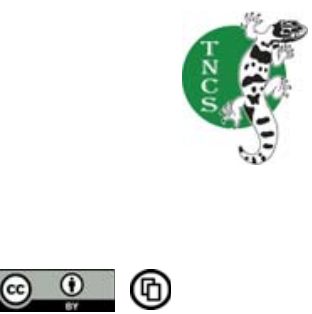

OPEN ACGESS | FREE DOWNLOAD
Abstract: The island of Sri Lanka has a heritage of astonishing biodiversity of which comparatively little remains, restricted to small forest islands. Conservation efforts have been aided by many high-quality publications, while on the other hand inaccurate reports can present obstacles to effective efforts. Here we discuss inaccuracies in a report prepared for the Department of Wildlife Conservation of Sri Lanka and the Ministry of Environment and Natural Resources, from which it is apparent that the consultants dominating conservation science do not appreciate the necessity of identifying species accurately, citing appropriate references, or updating their knowledge of current nomenclature and distribution of taxa. Conservation is an important national and international issue, and it is incumbent upon educators, conservation managers, legal advisors, funding agencies, officials and policy makers to work along with research scientists to ensure that inaccurate information does not endanger efforts to safeguard Sri Lanka's remaining endangered biodiversity treasures. Towards this end, procedures for the conduct of conservation studies should be revised to incorporate input from researchers familiar with current knowledge and methods.

Keywords: Inaccuracies, Taxonomy, Biodiversity Hotspots, Conservation Science, Consultancy, Ritigala Strict Nature Reserve, Sri Lanka

\section{INTRODUCTION}

Biodiversity conservation must proceed in the face of a host of threats and challenges, including deforestation (Brook et al. 2003), rapid climate change (Harvell et al. 2002; Alford et al. 2007; Rosa et al. 2007), invasive alien species (Elton 1958), pollution (MacNeely 1992), fire (Swinbanks, 1997; Batuwita \& Bahir 2005), soil erosion (Hewawasam et al. 2003), agro-chemical use (Pethiyagoda 1994; Hayes et al. 2002), infectious disease (Dazak et al. 2000; Pounds et al. 2006) and the lack of systematic or scientific understanding (Pethiyagoda 2007; Bahir 2009; Bahir \& Gabadage 2009). Biodiversity hotspots have been identified to prioritize conservation efforts (Stattersfield et al. 1998; Myers et al. 2000; Meegaskumbura et al. 2002; Mittermeier et al. 2004), with one of the most prominent and populous being the Western Ghats - Sri Lanka biodiversity region (Cincotta et al. 2000; Myers et al. 2000; Mittermeier et al. 2004). This region is divided in to several eco-regions (Wickramanayake et al. 2002), each unique in species diversity and endemism (Myers et al. 2000; Bossuyt et al. 2004, 2005; Helgen \& Groves 2005); for example molecular phylogenetic studies indicate that Sri Lanka has long maintained a fauna distinct from that of mainland India (Bossuyt et al. 2004). While we may lack the taxonomic knowledge and expertise to effectively describe the Earth's remaining biodiversity (Wilson 2005), it is important to conservation efforts that we make every effort possible to understand exactly what it is we are trying to protect (Evenhuis 2007).

The Sri Lanka Department of Wildlife Conservation has made reasonable progress towards identifying species diversity in selected protected areas, especially national parks and nature reserves. Biodiversity surveys, exploration, collection, documentation and reporting of existing diversity of populations and habitats (Pethiyagoda 2005; Evenhuis 2007) are all essential to effective conservation efforts (it is especially important to assess conservation status at species level, IUCN 2001; IUCN 2007). While the Department lacks conservation scientists and researchers, it has sought scientific input from outside (DWC 1997, 2005, 2007a, 2007b, 2007c, 2007d, 2008), for example conservation managers have consulted experts to document the diversity in key areas in order to prioritize conservation efforts (DWC 2007d, 2008).

Obviously, if it is to guide effective conservation management, expert information must be relevant, timely, comprehensive and accurate. It is also reasonable to expect that consultancy services which are well remunerated for their efforts (eg. DWC 2005; 2007a; $2007 \mathrm{~b} ; 2007 \mathrm{c} ; 2007 \mathrm{~d}$; 2008) should produce work of a high standard, free of gross errors and inaccuracies. Unfortunately, we have observed that these standards and 
expectations are not met by a recent consultancy report published to popularize conservation in Ritigala Strict Nature Reserve (DWC 2008): "Consultancy Services Report, Biodiversity baseline survey: Ritigala Strict Natural Reserve" (funded by the Department of Wildlife Conservation through Asian Development Bank loan number 1767-SRI (SF)).

In this article we highlight the serious errors and inaccuracies contained in DWC (2008), many of which perpetuate taxonomic inaccuracies that have recently been corrected in the scientific literature (Pethiyagoda 2007; Bahir 2009; Bahir \& Gabadage 2009). These deficiencies demonstrate how important it is for biodiversity consultants to be cognizant of current scientific literature, nomenclature and species identification. Otherwise, biodiversity surveys and other expert inputs will simply result in a waste of funds in the production of information that likely to be of little help in the conservation of our remaining biodiversity.

\section{Inaccuracies in Biodiversity Baseline Survey: Ritigala Strict Natural Reserve}

1. Errors in references and citations: The report refers to a widely recognized work on Sri Lankan flora (Dassanayake \& Fosberg 1980-1991; Dassanayake et al. 1994-1995; Dassanayake \& Clayton 1996-2000), but it is not listed under References. Rather than individually cite the contributions of several authors concerning the fauna of Sri Lanka and the status of taxonomy, research and conservation, the contents of the compilation edited by Bambaradeniya are simply referenced as Bambaradeniya (ed.) 2006. This neglects the input of researchers who contributed the findings of years of work to a national program to prioritize conservation, organized by the Ministry of Environment and Natural Resources together with IUCN. The editor of a compilation (in this case Bambaradeniya) is not the person responsible for the research, findings and opinions of its contributors. Only some of the articles from that document were relevant to the groups studied in the survey, which included fresh water fish (Amarasinghe et al. 2006; Pethiyagoda 2006), amphibians (Pethiyagoda et al. 2006); reptiles (de Silva 2006), birds (Kotagama et al. 2006; Warakagoda \& Sirivardana 2006) and mammals (Miththapala 2006; Weerakoon \& Goonatilake 2006; Wijesinghe 2006).

2. Errors in presenting data and nomenclature: The report states that "The Eastern drainage supports the endemics Chela laubuca, Esomus thermoicos, Puntius amphibious and Puntius ticto". Actually, species previously recognized as Chela Hamilton, 1822 from Sri Lanka are now recognized as belonging to the genus Laubuca (Pethiyagoda et al. 2008). Laubuca laubuca (Hamilton 1882) was described from Bengal, but recent research shows that in Sri Lanka the genus has four endemic species (Pethiyagoda 2008). Species around Ritigala Strict Nature Reserve should be identified accurately; perhaps the species recorded by the consultants is Laubuca lankensis (Deraniyagala 1960). Puntius amphibious (Valenciennes, in Cuvier \& Valenciennes 1842) is probably an extinct species described from Mumbai, India, and there only two specimens of this species are extant- MNHN 73 (Silva et al. 2008). Fish identified previously from Sri Lanka as P. amphibius (Pethiyagoda 1991), are now recognized as an endemic species, $P$. kamalika (Silva et al. 2008), which is restricted to the wet zone. The consultants in DWC (2008) probably identified a juvenile P. dorsalis (Jerdon, 1849), juvenile P. sarana (Hamilton 1822) or some other cyprinid fish as Puntius amphibious.

P. ticto (Hamilton, 1822) was described from Bengal. Deraniyagala (1956) gave a name to the P. ticto like fish in Sri Lanka, describing it as $P$. ticto melanomaculatus. At present $P$. ticto melanomaculatus is not recognized as a valid taxon (Pethiyagoda 1991). Recent molecular investigations show marked differences between $P$. ticto and $P$. melanomaculatus (Meegaskumbura et al. 2008).

The report says of the freshwater fish diversity of Ritigala: "Five species are endemic, representing $11 \%$ of the 44 species endemic to Sri Lanka”. In reality, as of the end of August 2008, 35 species were endemic to Sri Lanka (Pethiyagoda 1991, 1998; Pethiyagoda \& Kottelat 2005; Meegaskumbura et al. 2008; Pethiyagoda et al. 2008; Silva et al. 2008). It is evident, as demonstrated (Bossuyt et al. 2004) on the evidence of two invertebrate and four vertebrate groups, that the biotic interchange is more limited than has been assumed, and that Sri Lanka has maintained a fauna that is largely distinct from the mainland. Many species of animals will probably turn out to be endemic after taxonomic comparisons, as has been shown recently (Groves \& Meijaard 2005; Pethiyagoda \& Kottelat 2005). Nonetheless, there is a danger of listing species as endemic without evidence (Pethiyagoda 2006; Goonetileke 2007). In "Freshwater fishes of Sri Lanka", the author unwittingly published statements of Pethiyagoda (see Goonetileke 2007), without knowing the seriousness of taxonomic issues. It is rather unfortunate that the consultants did not preserve any voucher specimens of freshwater fish in their survey, so the identity of their species can not be confirmed. To obtain collection permission from the Department of Wildlife Conservation is difficult for bona fide scientists (Pethiyagoda et al. 2007), but unfortunately conservationists in many cases get permission to collect specimens in their studies without any taxonomists to identify them accurately (DWC 2007d, 2008). Consultants actually misused their opportunity of preserving voucher specimens though they had permission to make collections (DWC 2008). Current procedures for systematics and conservation science by the authorities in Sri Lanka should be improved or reassessed up to international standards of taxonomy and conservation science.

The authors of the consultancy report, in table 3.2 under the category herpetofauna, give the total voucher specimens collected as three, and the total voucher specimens identified as 11 and two unidentified (DWC 2008). But in Annex 3, they provide the information for 13 specimens as collected. As over 30 consultants worked on the project, this is a regrettable situation.

DWC, 2008 records three species of Agamid lizards, namely Otocyptis nigristigma Bahir \& Silva, 2005, Calotes ceylonensis Müller, 1887 and Calotes liolepis Boulenger, 1885. They state: "Interestingly, the endemic and vulnerable whistling lizard is normally not recorded elsewhere in the Dry Zone". However, Bahir \& Maduwage (2005) recorded Calotes liolepis from 22 localities within Sri Lanka, and four of those are from the dry zone including Ritigala Strict Nature Reserve; their records were confirmed by preserved specimens. The consultants of DWC (2008) are clearly not familiar with the recent literature and the recorded distributions of the species that they study. It might have been interesting and important to point out in the report that the type locality of Otocryptis nigristigma is actually Ritigala Strict Nature Reserve itself (Bahir \& Silva 2005). 
The report records Cyrtodactylus fraenatus (Günther 1864) from Ritigala, but the species in Ritigala is actually a species new to science and will be described in the near future. Recent studies on Sri Lankan Cyrtodactylus Gray 1827 uncovered five new species, each restricted to a small range (Batuwita \& Bahir 2005).

DWC, 2008 records Cnemaspis jerdonii (Theobald 1868) from Ritigala Strict Nature Reserve. Actually C. jerdonii was described from India (Theobald 1868) and is known only from two poorly-preserved specimens (Manamendra-Arachchi et al 2007). Ferguson (1887), described a species from Kandy Hills as Gymnodactylus scalpensis. Recent research results have shown it as a valid species of Cnemaspis, C. scalpensis, which is endemic to hills around Kandy (Manamendra-Arachchi et al. 2007). Given this history, the species reported from Ritigala by the consultants perhaps represents a further undescribed species.

The consultants recorded the endemic Sri Lankan hanging parrot (Loriculus beryllinus), but they did not mention that it is endemic (DWC 2008). A recent publication on birds recognized three species of corvids from Sri Lanka (Rasmussen \& Anderton 2005), but in the consultancy report it states that there are 13 species of corvid birds in Ritigala Strict Nature Reserve. It appears to us that the authors are depending on previous publications and not familiar with recent research findings. The consultants recorded two bird species, Tephrodornis pondicerianus (Gmelin 1789) (Common Woodshrike) and Mirafra assamica Horsfield 1840 (Bengal Bushlark), from Ritigala, but Rasmussen \& Anderton (2005) clearly state that these two birds are not yet recorded in Sri Lanka; it is not clear on what evidence this consultancy work extends the distribution of these two species to Sri Lanka.

The consultants record 17 species of amphibians in their study, but their nomenclature is woefully out of date. Recently Frost et al. (2006) reviewed the nomenclature of amphibians on a global scale; this is available freely online (Frost et al. 2006; Frost el al. 2009). Despite this, the consultants overlooked the description of the new genus Duttaphrynus Frost et al. 2006 and the evidence of the validity of Hylarana. Bufo melanostictus Schneider, 1799 and Rana gracilis Gravenhorst, 1829 should be referred as Duttaphrynus melanostictus and Hylarana gracilis, respectively. It is unexpected that an amphibian specialist group representative in the IUCN Species Survival Commission also worked as a consultant in DWC (2008), yet still did not take account of these advances.

\section{Conclusion}

Among the books and research papers not cited by the consultants in their final refined assessment of the diversity in Ritigala Strict Nature Reserve are the following: (Legge 1880; Deraniyagala 1953, 1956, 1960; Taylor 1953; de Silva 1980; Phillips 1980-1984; Senanayake \& Moyle 1982; de Silva 1990; Sibley \& Monroe 1990; Pethiyagoda 1991, 1994, 1998; Kotagama \& Fernando 1994; Manamendra-Arachchi \& Liyanage 1994; Bandara \& Mahatantila 1996; Das 1996; Dutta \& Manamendra-Arachchi 1996; Priyadharshana \& Fernando 1996; Henry 1998; Harrison 1999; Kluge, 2001; Meegaskumbura et al. 2002; Bossuyt et al. 2004, 2005; Stuart et al. 2004; Bahir \& Maduwage 2005; Bahir \& Silva 2005; Bahir \& Surasinghe 2005; Batuwita \& Bahir 2005; Groves \& Meijaard 2005; Helgen \& Groves 2005; Manamendra-Arachchi \& Pethiyagoda 2005; Frost et al. 2006; Manamendra-Arachchi et al. 2007; Pethiyagoda et al. 2008; Silva et al. 2008). None of these sources are cited or referred in the final report, which we find puzzling. Reading the report, is not clear how the consultants identified the species concerned; these references, and others not mentioned here, should have been listed, in particular because they did in fact cite several in the text which nonetheless did not appear in the References Cited list. We ask following questions: Is this because the consultants are not aware of these relevant publications? Answer: No, because some of those publications are already referred by them in DWC (2007b). We believe the final report also should have provided all relevant references to enable readers to understand the project and its context. Are the consultants themselves active researchers and/or scientists? Have they published research papers in international journals in their respected fields? How are consultants chosen, and what is the policy behind the appointment of consultants in any given program?

We assume that popular conservationists are dominating the field of biodiversity science in Sri Lanka, and that this is perhaps true for many other biodiversity hotspots as well. However, taxonomists with specialist knowledge of the groups being investigated must always be part of area assessments, especially within biodiversity hotspots. Taxonomists are responsible for laying the foundations of conservation science (Evenhuis 2007), and when starting conservation projects the description of species should be considered. This consultancy report is a sobering example for biodiversity surveys in the Western Ghats-Sri Lanka biodiversity hotspot. In our opinion, the procedures for the appointment of consultants to conduct such studies should be revised, and genuine researchers should get the opportunity to contribute to the conservation of the country's vanishing biodiversity heritage. While it is true that some scientists have argued that the only value of type specimens is scientific (Pethiyagoda et al. 2007), we would like to argue that they also have heritage value.

We request that authors of educational materials (e.g. journalists, authors of school text books and field guides) and students, conservation managers, policy makers and conservation scientists, read and refer to consultancy reports with a critical eye, and not blindly accept them as some kind of "gold standard". When taxonomists and other researchers offer their data to produce reports or chapters of conservationoriented publications, there is a responsibility for publishers and responsible authorities to take their contributions seriously. To take only the most glaring example, the editor of a multiauthored compilation (e.g., Bambaradeniya 2006) must not be the one to receive the citations; he or she presumably has a hand in choosing the authors of the various contributions, but beyond that he/she is in no way responsible for what they write. It is mandatory for amateur naturalists, taxonomists, conservation scientists, conservation managers, government officials, legal advisors, policy makers and politicians to pay serious attention to solving matters of this nature, especially on a consultancy level. Otherwise, conservation science and biodiversity research in Sri Lanka will perish. This is an issue to be argued nationally and internationally; in Sri Lanka, a unique jewel of biodiversity, much of what comparatively little remains is now trapped in small forest islands at the mercy of the success of conservation efforts. It is incumbent upon conservation managers, funding agencies and policy makers to work along with research scientists to safeguard the island's 
vanishing natural heritage.

\section{References}

Alford, R.A., K.S. Bradfield \& S.J. Richards (2007). Global warming and amphibian losses: the proximate cause of frog decline? Nature 447: E3-E4.

Amarasinghe, U.S., R.R.R.A. Shirantha \& M.J.S. Wijeyaratne (2006). Some aspects of ecology of endemic fresh water fishes of Sri Lanka, pp. 113-124. In: Bambaradeniya C. (ed.), Fauna of Sri Lanka: Status of Taxonomy, Research and Conservation. The World Conservation Union, Colombo, Sri Lanka and Government of Sri Lanka, viii+308pp

Bahir, M.M. (2009). Some taxonomic inaccuracies in conservation publications. Current Science 96 (5): 631-632.

Bahir, M.M. \& K.P. Maduwage (2005). Calotes desilvai, a new agamid lizard from Morningside Forest, Sri Lanka. In: D. C. J Yeo, P. K. L. Ng \& R. Pethiyagoda (eds.), Contributions to biodiversity exploration and research in Sri Lanka. The Raffles Bulletin of Zoology, Supplement No. 12: 381-392.

Bahir, M.M. \& A. Silva (2005). Otocryptis nigristigma, a new species of agamid lizard from Sri Lanka. In: Yeo, D.C.J., P.K.L. Ng \& R. Pethiyagoda (eds.), Contributions to biodiversity exploration and research in Sri Lanka. The Raffles Bulletin of Zoology, Supplement No. 12: 393-406.

Bahir, M.M. \& T.A. Surasinghe (2005). Conservation assessment of the Sri Lankan Agamidae (Reptilia: Sauria). In: D.CJ. Yeo, P.K.L. Ng \& R. Pethiyagoda (eds.), Contributions to biodiversity exploration and research in Sri Lanka. The Raffles Bulletin of Zoology, Supplement No. 12: 407-412.

Bahir, M.M \& D.E. Gabadage (in press). Taxonomic errors and inaccuracies in Sri Lankan Red List: a cautionary note. Journal of Threatened Taxa.

Bambaradeniya, C.N.B. (ed.) (2006). The fauna of Sri Lanka: status of taxonomy. research and conservation. The World Conservation Union, Colombo, Sri Lanka \& Government of Sri Lanka, Colombo, Sri Lanka. 308pp.

Bandara, N.M.S.A. \& K.C.P. Mahatantila (1996). A survey of medicinal plants in Ritigala and its surrounding plain. Sri Lanka Forester 22: 321.

Batuwita, S. \& M.M. Bahir (2005). Description of five new species of Cyrtodactylus (Reptelia: Gekkonidae) from Sri Lanka. In: Yeo, D.C.J., P.K.L. Ng \& R. Pethiyagoda (eds.). Contributions to biodiversity exploration and research in Sri Lanka. The Raffles Bulletin of Zoology, Supplement No. 12: 351-380.

Bossuyt, F., M. Meegaskumbura, N. Beenaerts, D.J. Gower, R. Pethiyagoda, K. Roelants, A. Mannaert, M. Wilkinson, M.M. Bahir, K. Manamendra-Arachchi, P.K.L. Ng, C. J. Schneider, O.V. Oommen \& M.C. Milinkovitch (2004). Local endemism within the Western Ghats-Sri Lanka Biodiversity Hotspot. Science 306: 479-481.

Bossuyt, F., M. Meegaskumbura, N. Beenaerts, D.J. Gower, R. Pethiyagoda, K. Roelants, A. Mannaert, M. Wilkinson, M.M. Bahir, K. Manamendra-Arachchi, P.K.L. Ng, C. J. Schneider, O. van Oomen \& M.C. Milinkovitch (2005). Biodiversity in Sri Lanka and Western Ghats. Science 308: 199.

Brook, B.W., N.S. Sodhi. \& P.K.L. Ng (2003). Catastrophic extinctions follow deforestation in Singapore. Nature 424: 420-423.

Cincotta, R.P., J. Wisnewski, \& R. Engelman (2000). Human populations in the biodiversity hotspots. Nature 404: 990-992.

Das, I. (1996). Biogeography of the reptiles of South Asia. Krieger Publishing Co., Malabar, Florida. 87pp.

Dassanayake, M.D., \& F.R. Fosberg, (eds.) (1980-1991). A revised handbook to the flora of Ceylon. Oxford \& IBH Publishing Co., New Delhi. vol. I vii+508; vol. II. vii+511pp; vol. III. vii+499pp; vol. IV. vii+532pp; vol. V. vii+476; vol. VI. vii+424pp vol. VII. Vii+439pp.

Dassanayake, M.D., F.R. Fosberg, \& W.D. Clayton (eds.) (1994-1995). A Revised Handbook to the Flora of Ceylon. Oxford \& IBH Publishing Co., New Delhi. vol. VIII. v+458; vol. IX. v+482pp.

Dassanayake, M.D. \& W.D. Clayton (eds.) (1996-2000). A Revised Handbook to the Flora of Ceylon. Oxford \& IBH Publishing Co., New Delhi. vol. X. viii+426pp; vol. XI. 420pp; vol. XII. 390pp; vol. XIII. 284pp; vol. XIV. v+307.
Daszak, P., A.A. Cunningham \& A.D. Hyatt (2000). Emerging infectious diseases of wildlife threats to biodiversity and human health. Science 287: 443-449.

Deraniyagala, P.E.P. (1953). A Colored Atlas of Some Vertebrates from Ceylon. Vol. 2. Ceylon National Museums, Colombo, $101 \mathrm{pp}$.

Deraniyagala, P.E.P. (1956). Two new sub species and one new species of cyprinoid fishes from Ceylon. Proceedings of the $12^{\text {th }}$ Annual Session of the Ceylon Association for the Advancement of Science 1: 34-35.

Deraniyagala, P.E.P. (1960). A new subspecies of fish Chela labuca from Ceylon. Spolia Zeylanica 29: 17.

de Silva, A. (1990). Colour guide to the snakes of Sri Lanka. R \& A Publishing Ltd., Portishead, England, 130pp.

de Silva, A. (2006). Current status of reptiles of Sri Lanka. Fauna of Sri Lanka: 134-163. In: Bambaradeniya C. (ed.), Fauna of Sri Lanka: Status of Taxonomy, Research and Conservation. The World Conservation Union, Colombo, Sri Lanka and Government of Sri Lanka. 308pp.

de Silva, P.H.D.H. (1980). Snake fauna of Sri Lanka, with special reference to skull, dentition and venom in snakes. National Museum, Colombo, $\mathrm{xi}+472 \mathrm{pp}$.

DWC (1997). Resources inventory of Ritigala Strict Natural Reserve. Volume I. The global Environment Facility Project, UNDP and Department of Wildlife Conservation Project, Department of Wildlife Conservation, Colombo, $147 \mathrm{pp}$.

DWC (2005). Ritigala Strict Nature Reserve and very important proposed Yan Oya National Park: Management Plan. Final Draft. Protected Area Management and Wildlife Conservation Project, Department of Wildlife Conservation, Colombo, 113pp.

DWC (2007a). Biodiversity Baseline Survey: Field Manual. Consultancy Service Report prepared by M.J.B. Green, (ed.), S.M.D.A.U. De Alwis, P.N. Dayawansa, R. How, U.K. G.K. Padmalal, S. De Silva, B.M.P. Singhakumara, D. Weerakoon, M.R. Wijesinghe \& W.B. Yapa, ARD Inc in association with Infotech IDEAS and GREENTECH Consultants. Sri Lanka Protected Areas Management and Wildlife Conservation Project (PAM \& WCP/CONSULT/02/BDBS), Department of Wildlife Conservation, Ministry of Environment and Natural resources, Colombo, 43pp.

DWC (2007b). Biodiversity Information Management System: Users Guide. Consultancy Services Report prepared by S. De Silva, ARD Inc in association with Infotech IDEAS and GREENTECH consultants, Sri Lanka Protected Area Management and Wildlife Conservation Project (PAM \& WCP/CONSULT/02/BDBS), Department of Wildlife Conservation, Ministry of Environment and Natural Resources, Colombo, 16pp.

DWC (2007c). Biodiversity Information Management System: Technical Desighn Guide. Consultancy Services Report prepare by S. De Silva, ARD Inc in association with Infotech IDEAS and GREENTECH Consultants. Sri Lanka Protected Area Management and Wildlife Conservation Project (PAM \& WCP/CONSULT/02/BDBS), Department of Wildlife Conservation, Ministry of Environment and Natural Resources, Colombo, 9pp.

DWC (2007d). Biodiversity Baseline Survey: Ritigala Strict Natural Reserve. Consultancy services report prepared by M.J.B. Green (ed.), S.M.D.A.U.De Alwis, P.N. Dayawansa, R. How, B.M.P. Singhakumara, D. Weerakoon, M.R. Wijesinghe \& W. B.Yapa, ARD Inc. in association with Infotech IDEAS and GRENTECH Consultants. Sri Lanka protected areas management and Wildlife Conservation Project (PAM\&WCP/CONSULT/O2,BDBS), Department of Wildlife Conservation, Ministry of Environment and Natural Resources, Colombo, $41 \mathrm{pp}$.

DWC (2008). Biodiversity Baseline Survey: Ritigala Strict Natural Reserve. Revised version. Consultancy services report prepare by M.J.B. Green (ed.), S.M.D.A.U. De Alwis, P.N. Dayawansa, R. How, B.M.P. Singhakumara, D. Weerakoon, M.R. Wijesinghe \& W.B. Yapa, Infotech IDEAS in associan with GRENTECH Consultants. Sri Lanka protected areas management and Wildlife Conservation Project (PAM \& WCP/CONSULT/02,BDBS), Department of Wildlife Conservation, Ministry of Environment and Natural Resources, Colombo, 46pp.

Dutta, S.K. \& K. Manamendra-Arachchi (1996). The Amphibian Fauna of Sri Lanka. Wildlife Heritage Trust of Sri Lanka, Colombo, 232pp.

Elton, C.S. (1958). The Ecology of Invasions by Animals and Plants. London, Methuen, $181 \mathrm{pp}$. 
Evenhuis, N.L. (2007). Helping solve the "Other" taxonomic impediment: completing the eight steps to total enlightenment and taxonomic nirvana. Zootaxa 1407: 3-12.

Ferguson, W. (1887). Reptile fauna of Ceylon. Letter on a collection sent to the Colombo Museum. Herbert, Ceylon. Government Press, Ceylon, 12-13.

Frost, D.R., T. Grant, J. Faivovich, R.H. Bain, A. Haas, C.F.B. Haddad, R.O. de Sá, A. Channing, M. Wilkinson, S.C. Donnellan, C.J. Raxworthy, J.A. Campbell, B.L. Blotto, P. Moler, R.C. Drewes, R.A. Nussbaum, J.D. Lynch, D.M. Green, \& W.C. Wheeler (2006). The Amphibian Tree of Life. Bulletin of the American Museum of Natural History 297: 1-370.

Frost, D.R. (2009). Amphibian Species of the World: an Online Reference. Version 5.3 (12 February, 2009). Electronic Database accessible at http://research.amnh.org/herpetology/amphibia/American Museum of Natural History, New York, USA.

Goonatilake, S. de A. (2007). Freshwater fishes of Sri Lanka. Biodiversity Secretariat \& Ministry of Environment \& Natural Resources, Colombo, Sri Lanka, 134pp.

Groves, C.P. \& E. Meijaard (2005). Interspecific variation in Moshiola, the Indian chevrotain. In: Yeo, D.C.J., P.K.L. Ng \& R. Pethiyagoda (eds.), Contributions to biodiversity exploration and research in Sri Lanka. The Raffles Bulletin of Zoology, Supplement No. 12: 351-380.

Harrison, J. (1999). A field guide to the birds of Sri Lanka. Oxford University Press, Oxford, $219 \mathrm{pp}$.

Harvell, C.W., C.E. Mitchell, J.R. Ward, S. Altizer, A.P. Dobson, R.S. Ostfeld \& M.D. Samuel (2002). Climate warming and disease risks for terrestrial and marine biota. Science 296: 2158-2162.

Hayes, T., K. Haston, M. Tsui, A. Hoang, C. Haeffele \& A. Vonk (2002). Feminization of male frogs in the wild. Nature 419: 895896.

Helgen, K.M. \& C.P. Groves (2005). Biodiversity in Sri Lanka and Western Ghats. Science 308: 199.

Henry, G.M. (1998). A guide to the birds of Sri Lanka. Third Edition: revised and enlarged by T.W. Hoffmann, D. Warakagoda \& U. Ekanayake. Oxford University Press, London \& K.V.G. de Silva \& Sons, Kandy, 488pp.

Hewawasam, T., F. von Blanckenburg, M. Schaller \& P. Kubik (2003). Increase of human over natural erosion rates in tropical highlands constrained by cosmogenic nuclides. Geology 31: 597-600.

IUCN (International Union for the Conservation of Nature and Natural Resources) (2001). IUCN Red List, categories and criteria: version 3.1. IUCN Species Servival Commission. IUCN, Gland, Switzerland and Cambridge, UK. ii+30pp.

IUCN Sri Lanka \& the Ministry of Environment and Natural Resources. (2007). The Red List of threatened fauna and flora of Sri Lanka. Colombo, Sri Lanka, xiii+148pp.

Kluge, A.G. (2001). Gekkotan lizard taxonomy. Hamadryad 26: 1-209.

Kotagama. S.W. \& P. Fernando. (1994). A field guide to the birds of Sri Lanka. Wildlife Heritage Trust. Colombo, 224pp.

Kotagama, S.W., R.I. de Silva, A.S. Wijesinghe \& V. Abeyagunawardane (2006). Avifaunal list of Sri Lanka pp. 164-203. In: Bambaradeniya, C. (ed.). Fauna of Sri Lanka: Status of Taxonomy, Research and Conservation. The World Conservation Union, Colombo, Sri Lanka and Government of Sri Lanka, viii+308pp.

Legge, W.V. (1880). A History of the Birds of Ceylon (1983 edition) in 4 Vols. Thisara Prakashakayo Ltd., Dehiwala, Sri Lanka, 1882pp.

Manamendra-Arachchi, K. \& S. Liyanage (1994). Conservation of the agamid lizards of Sri Lanka with illustrations of the extant species. Journal of the South Asian Natural History 1: 77-96.

Manamendra-Arachchi, K. \& R. Pethiyagoda (2005). The Sri Lankan shrub-frogs of the genus Philautus Gistel, 1848 (Ranidae: Rhacophorinae), with description of 27 new species. In: Yeo, D.C.J., P.K.L. Ng \& R. Pethiyagoda (eds.), Contributions to biodiversity exploration and research in Sri Lanka. The Raffles Bulletin of Zoology, Supplement No. 12: 163-303.

Manamendra-Arachchi, K., S. Batuwita \& R. Pethiyagoda (2007). A taxonomic revision of the Sri Lankan day-geckos (Reptilia: Gekkonidae: Cnemaspis), with description of new species from Sri Lanka and Southern India. Zeylanica 7(1): 9-122.

McNeely, J.A. 1992. The sinking ark: pollution and the worldwide loss of biodiversity. Biodiversity \& Conservation 1: 2-18.
Meegaskumbura, M., F. Bossuyt, R. Pethiyagoda, K. ManamendraArachchi, M. Bahir, M. Milinkovitch \& C. Schneider (2002). Sri Lanka: an amphibian hotspot. Science 298: 379.

Meegaskumbura, M., A. Silva, K. Maduwage \& R. Pethiyagoda (2008). Puntius reval, a new barb from Sri Lanka (Teleostei: Cyprinidae). Ichthyological Exploration of Freshwaters 19: 141-152.

Miththapala, S. (2006). The ecology of the wild cats of Sri Lanka, pp 235-256. In: Bambaradeniya C. (ed.), Fauna of Sri Lanka: Status of Taxonomy, Research and Conservation. The World Conservation Union, Colombo, Sri Lanka and Government of Sri Lanka, viii+308pp.

Mittermeier, R.A., P.R. Gil, M. Hoffman, J. Pilgrim, T. Brooks, C.G. Mittermeier, J. Lamoreux \& G.A.B. da Fonseca (2004). Hotspots revisited: earth's biologically richest and most threatened terrestrial ecoregions. CEMEX, Mexico City and Conservation International, Washington, D.C. $392 \mathrm{pp}$.

Myers, N., R.A. Mittermeier, G.A.B. da Fonseca \& J. Kent (2000). Biodiversity hotspots for conservation priorities. Nature 403: 853857.

Pethiyagoda, R. (1991). Freshwater Fishes of Sri Lanka. Wildlife Heritage Trust, Colombo, xiii+362pp.

Pethiyagoda, R. (1994). Threats to the indigenous freshwater fishes of Sri Lanka and remarks on their conservation. Hydrobiologia 285(13): $189-201$.

Pethiyagoda, R. (1998). Ours to Protect Sri Lanka's Biodiversity Heritage Wildlife Heritage Trust, Colombo, 156pp.

Pethiyagoda, R. (2005). Exploring Sri Lanka's biodiversity. In: Yeo, D.C.J., P.K.L. Ng \& R. Pethiyagoda (eds.), Contributions to biodiversity exploration and research in Sri Lanka. The Raffles Bulletin of Zoology, Supplement No. 12: 1-4.

Pethiyagoda, R. (2006). Conservation of Sri Lankan Freshwater Fishes, pp. 103-112. In: Bambaradeniya C. (ed.), Fauna of Sri Lanka: Status of Taxonomy, Research and Conservation. The World Conservation Union, Colombo, Sri Lanka and Government of Sri Lanka, viii+308pp.

Pethiyagoda, R. (2007). The 'New species syndrome' in Sri Lankan herpetology: a cautionary note. Zeylanica 7(1): 1-7.

Pethiyagoda, R. \& M. Kottelat (2005). A revision of the barbs of the Puntius filamentosus group (Teleostei: Cyprenidae) of Southern India and Sri Lanka. In: Yeo, D.C.J., P.K.L. Ng \& R. Pethiyagoda (eds.), Contributions to biodiversity exploration and research in Sri Lanka. The Raffles Bulletin of Zoology, Supplement No. 12: 127-144.

Pethiyagoda, R., K. Manamendra-Arachchi, M.M. Bahir \& M. Meegaskumbura (2006). Sri Lankan Amphibians: Diversity, uniqueness and conservation, pp. 125-133. In: Bambaradeniya C. (ed.). Fauna of Sri Lanka: Status of Taxonomy, Research and Conservation. The World Conservation Union, Colombo, Sri Lanka and Government of Sri Lanka, viii+308pp.

Pethiyagoda, R., N. Gunatilleke, M. de Silva, S. Kotagama, S. Gunatilleke, P. de Silva, M. Meegaskumbura, P. Fernando, S. Ratnayeke, J. Jayewardene, D. Raheem, S. Benjamin \& A. Ilangakoon (2007). Science and biodiversity: the predicament of Sri Lanka. Current Science 92(4): 426-427.

Pethiyagoda, R., M. Kottelat, A. Silva, K. Maduwage \& M. Meegaskumbura (2008). A review of Laubuca in Sri Lanka, with description of three new species (Teleostei: Cyprinidae). Ichthyological Exploration of Freshwaters 19(1): 7-26.

Phillips, W.W.A. (1980-1984). Manual of the mammals of Sri Lanka, $2^{\text {nd }}$ revised edition in 3 Vols. Wildlife and Nature Protection Society, Colombo, Sri Lanka. vol. I. xxix+116pp; vol.II. xi+117-267pp; III xiv $+268-389$ p.

Pounds, A.J., M.R. Bastamante, L.A. Coloma, J.A. Consuegra, M.P.L. Fogden, P.N. Foster, E. La Marca, K.L. Masters, A. Merno-Viteri, R. Puschendorf, S.R. Ron, G.A. Sanchez-Azofeifa, C.J. Still \& B.E. Young (2006). Widespread amphibian extinctions from epidemic disease driven by global warming. Nature 439: 161-167.

Priyadarshana, T.G.M. \& S.S. Fernando (1996). Biological Exploration of Ritigala Strict Nature Reserve. News Letter of Young Zoologists Association of Sri Lanka 4: 5-8.

Rasmussen, P.C. \& J.C. Anderton (2005). The Birds of South Asia: The Ripley Guide, Smithsonian Institution and Lynx Editions, Washington D.C. in 2 Vols. Vol. I 378pp \& vol. II 683pp.

Rosa, I.D., F. Simonselli, A. Fagotti, \& R. Pascoline (2007). The 
proximate cause of frog decline?. Nature 447: E4-E5.

Senanayake, F.R. \& P.B. Moyle (1982). Conservation of fresh water fishes of Sri Lanka. Biological Conservation 22: 181-195.

Sibley, C.G. \& B.L. Monroe (1990). Distribution and Taxonomy of the Birds of the world. Yale University Press, New Haven \& London, $1111 \mathrm{pp}$.

Silva, A., Maduwage K. \& R. Pethiyagoda (2008). Puntius kamalika, a new species of barb from Sri Lanka (Teleostei: Cyprinidae). Zootaxa 1824: $55-64$.

Stattersfield, A.J., M.J. Crosby, A.J. Long \& D.C. Wege (1998). Endemic Bird Areas of the World: priorities for biodiversity conservation. BirdLife International, No. 7. Cambridge, 846pp.

Stuart, S., J.S. Chanson, N.A. Cox, B.E. Young, A.S.L. Rodrigues, D.L. Fischman \& R.W. Waller (2004). Status and trends of amphibian declines and extinctions worldwide. Science 306: 1783-1786.

Swinbanks, D. (1997). Forest fires cause pollution crisis in Asia. Nature 389: 321 .

Taylor, E.H. (1953). A review of the lizards of Ceylon. University of Kansas Science Bulletin 35: 1536-1537.

Theobald, W. (1868). Catalogue of reptiles in the Museum of the Asiatic Society of Bengal. Journal of the Asiatic Society of Bengal, (Extra number 88) 37: 1-88.

Warakagoda, D. \& U. Sirivardana (2006). Status of waterfowl in Sri Lanka, pp. 104-215. In: Bambaradeniya C. (ed.). Fauna of Sri Lanka:
Status of Taxonomy, Research and Conservation. The World Conservation Union, Colombo, Sri Lanka and Government of Sri Lanka. viii+308pp.

Weerakoon, D.K. \& W.L.D.P.T.S. de Goonatilake (2006). Taxonomic status of the mammals of Sri Lanka, pp. 216-231. In: Bambaradeniya C. (ed.). Fauna of Sri Lanka: Status of Taxonomy, Research and Conservation. The World Conservation Union, Colombo, Sri Lanka and Government of Sri Lanka. Viii+30spp.

Wikramanayake, E.D., E. Dinnerstein, C.J. Loucks, D.M. Olson, J. Morrison, J. Lamoreux, M. McKnight \& P. Hedao (2002). Terrestrial Ecoregions of the Indo-Pacific: A Conservation Assessment. Island Press, Washington, DC. Vol. 1, 643pp.

Wijesinghe, M.R. (2006). Ecological traits of endemic small mammals of rain forests of Sri Lanka, and their implications for conservation, pp. 132-234. In: Bambaradeniya C. (ed.). Fauna of Sri Lanka: Status of Taxonomy, Research and Conservation. The World Conservation Union, Colombo, Sri Lanka and Government of Sri Lanka, viii+308pp.

Wilson, E.O. (2005). Systematics and future of Biology. Proceedings of National Academy of Sciences USA 102: 6520-6521. 